\title{
NOTES FROM THE FIELD
}

\section{So Near Yet So Far: A Narrative from a Forest- dwelling Gaddi Community in Chamba, Himachal Pradesh}

Kritishnu Sanyal, ${ }^{*}$ Anupreet Kaur, ${ }^{* *}$ Shyamasree Dasgupta ${ }^{* * *}$

\section{INTRODUCTION}

"We exist as the trees exist", ${ }^{1}$ our respondent said with a chuckle when we asked how the surrounding forests helped her sustain. This was in one of the three Gaddi villages in the Chamba district of Himachal Pradesh (HP) that we visited between August 2019 and March 2020. The Gaddis are a semi-nomadic Scheduled Tribe who live mostly in parts of the western Indian Himalayan region. Agriculture and animal husbandry are their main sources of livelihood, and they practise winter migration. Because of the remoteness of our study location, other than a few research scholars, occasional tourists, and forest produce merchants, hardly anyone from the outside visits these villages. This note briefly narrates two significant observations from the site on how the Gaddi villagers perceive the "forest" as a natural resource and their thorough sense of alienation from the entire gamut of forest management practices. We interviewed people from 60 randomly selected households using a semi-structured questionnaire and

* Doctoral Student, School of Humanities and Social Sciences (SHSS), Indian Institute of Technology Mandi (IIT-M), Himachal Pradesh 175075, India; sanyalkritishnu@gmail.com. $\square$

** Project Associate, SHSS, IIT-M; anupreetk98@gmail.com.

*** Assistant Professor, SHSS, IIT-M; shyamasree.dasgupta@gmail.com.

Copyright (C) Sanyal, Kaur, Dasgupta 2021. Released under Creative Commons AttributionNonCommercial 4.0 International licence (CC BY-NC 4.0) by the author.

Published by Indian Society for Ecological Economics (INSEE), c/o Institute of Economic Growth, University Enclave, North Campus, Delhi 110007.

ISSN: 2581-6152 (print); 2581-6101 (web).

DOI: https://doi.org/10.37773/ees.v4i1.309

1 Exact quote: "Ped hain to hum bhi hain". Respondent: a 36-year-old schoolteacher (woman); date: 16 March 2020; time: 15:20 IST; location: Sirad; interviewer: Author 1. 
engaged in multiple other informal discussions that formed a part of a more extensive survey.

\section{BENEFITS FROM FOREST ECOSYSTEMS ARE TOO OBVIOUS TO REPORT}

The valuation of anything is related to its contribution toward achieving a specific goal (Costanza and Folke 1997, 49). Such goals vary between stakeholders. The "ecological identity" (Kumar and Kumar 2008, 818) of the stakeholder is significant in such value formation. Since the valuations of forest ecosystem services are mainly determined by experts attaching values to these services given their scientific knowledge, we wanted to explore whether the communities living in proximity to forestlands also similarly recognize their value.

To understand this, we first asked respondents to name the products/services that they collect/derive from the forest. The most frequent, spontaneous responses were "fodder" and "fuel wood". While most respondents also collected food items, such as Guchchbi and Lingdu, and medicinal plants, such as Banafsha and Nagchhatri, ${ }^{2}$ most forgot to mention these initially and reported these names only after further probing. This underreporting led us to question whether the villagers did it deliberately because they collected food items and medicinal plants without a licence. In some cases, a licence is required since the forest is not an open one. We found that for the most part, the villagers were unaware that a licence may be required or the type of forest (open or protected) from which they collected resources. So it seemed unlikely that the underreporting was deliberate. They expressed their point of view saying, "taking things is not taking advantage of, but getting necessary help from, the forest for sustenance" 3 and, "one can't be a thief in their own house". 4

2 "Guchchhi" (common morel mushroom, Morchella esculenta); "Lingdu" (fiddlehead fern, Matteuccia struthiopteris); "Banafsha" (Viola odorata); and "Nagchhatri" (Trillium govanianum).

${ }^{3}$ Exact quote: "Jungle se kuchh lena matlab jungle ka faida uthana thodi na hai; hum bas apni jarurat ke hisabsehi lete hai". Respondent: a 38-year-old farmer-cumcontractual labourer (woman); date: 26 August 2019; time: 17:08 IST; location: Jhikli Kugti; interviewer: Author 1.

${ }^{4}$ Exact quote: “Apne ghar pe to koi chori nahi karta na?" Respondent: a 22-yearold master's student-cum-small tea shop owner (man); date: 27 August 2019; time: 12:42 IST; location: Jhikli Kugti; interviewer: Author 1. 
The respondents primarily talked about "provisioning services" they derive from the forestland. But does that mean that they have no understanding of other ecosystem services such as "regulating", "supporting", and "cultural"? While our interviewees were mostly unaware of various supporting services (such as pollination, habitat, and soil fertility), they had an in-depth understanding of regulating services (carbon sequestration, climate control, watershed management, etc.). However, they thought that these were too obvious to mention and expressed amusement that we were asking such basic questions. They were most surprised when we asked them whether they could attach any monetary value to these services. Moreover, they were not aware of the market prices of fodder, fuel food, and food items - in most cases, they consumed the forest produce that they collected.

Evidently, a community that derives benefit from the forestland cannot easily place a value on it. Our interactions revealed that the process of value formation for the community was different from that of the external scientific community.

\section{PARTICIPATION IN FOREST MANAGEMENT: THE PAST AND THE PRESENT}

Forests in South Asia have historically been inhabited by several tribal and non-tribal communities, whose livelihoods significantly depend on forestlands (Lele 2019, 22). Following the drive for participatory forest management in the world and India in the 1990s, the Indian Forest Rights Act, 2006 (FRA) (MOTA 2007), recognized a "forest-dwelling scheduled tribe" community's right to "manage any community forest resource which they have been traditionally protecting and conserving for sustainable use" (Mo'TA 2007, 4). While the wishful belief is that the philosophy of forest management in India has shifted from a strict top-down model to a cooperative one, the question remains whether the communities feel the same way.

Most families in the studied villages had ancestral houses in which they had been living for many decades. They recalled traditional forest management practices based on deity institutions and the Rakha (the keeper) and Praza (the public) systems. These institutions are also mentioned in the works of Dhiman (2001, 932), Gupta (2006, 14), and Vasan and Kumar (2006, 332). Deity institutions, run by a Devta committee (pre-sixteenth century to the present), historically controlled, and still control, the social, cultural, moral, economic, and political lives of the villagers. In turn, the villagers protect the nearby forests from exploitation as they believe that the deities are settled in these forests and that transgressors will be duly punished. In the 
Rakha system (pre-sixteenth century to 1950), a villager was nominated and employed by the village community to guard the local forests and received remuneration from all the households. After the Indian Forest Department (IFD) was established in 1864, this system became partially institutionalized. The rakha became a joint employee of both the state and the local community and started receiving a small cash payment from the state along with community payments. This practice of the IFD paying the rakha was questioned and rejected in the neighbouring district of Kangra in 1924, resulting in the fall of the Rakba system in HP (Singh 1998). In the Praza system (1950-1980), with the mutual consent of all the villagers, the village pradhan (chief) nominated 10-15 members to be a part of a committee called the praza. The praza organized major social practices related to collective resource extraction and its use and management. However, all these systems were non-inclusive as these were mostly run and managed by the upper-caste Gaddis, and women's participation was nil.

The influence of traditional institutions has reduced over time, and, at present, there is no locally elected body to manage forests. Similar to the reality in the rest of the country, the current forest management system in HP follows a hierarchical structure, and legal rights are implemented through the state forest department. While HP has extensive experience in joint forest management, the studied area did not utilize any such institutionalized forest management practices. On one hand, while strong bureaucratic resistance has prevented the granting of communities' rights promised under the FRA in various parts of the country (Lele 2019, 26), the villagers here did not even know about the existence of the FRA.

The Gaddi community in the studied villages, with has a history of strong, traditional forest management practices, felt alienated from the present forest management system in the absence of participatory forest management processes: "Our forest is no longer 'our forest'; it has become government's forest. So whether we protect it or not doesn't matter". ${ }^{5}$ Now they only engage in a wide variety of centre and state government-run schemes and community development programmes and other livelihood projects. We found that government interventions in local communities were limited to recruiting villagers on a daily-wage basis for afforestation under schemes such as Sanjhi Van Yojna. The villagers expressed

\footnotetext{
${ }^{5}$ Exact quote: "Humare jungal ab humare nahi sarkar ke ban chuke hain. Isliye hum unki raksha kare iya na kare usse koi farak nahi padta". Respondent: a 60-yearold farmer (woman); date: 18 March 2020; time: 18:13 IST; location: Thathan; interviewer: Author 2.
} 
discontent about the fact that nobody ever asked them how the forestland should be managed. This made them reluctant to embrace existing forest management policies and they simply deflected them instead. There is no reason to believe that they criticize government policies for the sake of it. They appreciate the role of government forest policies with their attached legalities in promoting caste and gender equity, increasing canopy cover, etc., as all this may be difficult to achieve under traditional systems. However, they feel completely alienated from the entire discourse.

\section{REFLECTION}

The experiences of these villagers are not representative of all forest dependent communities, but definitely of some. We observe that there is a difference between the process of value formation for forest products and services between the local community and the external scientific community. The Gaddi villagers did not even spontaneously recognize some of the important services because they felt that they were too obvious. We believe that this is one of the reasons why we see significant underreporting of forest produce collection in the existing literature. For forest management, there was neither a "politics of collaboration" nor a "politics of partnership" (Guha 2001, 232-233). The community experienced a transition from traditional participatory "forest management system" practices to participating in "forest conservation" as wage labourers. Therefore, while the academic discourse and philosophical standpoints of forest policies thrive on stating that the community as a stakeholder should participate significantly in managing forests within a legal framework established by the state, our field study revealed quite the opposite.

\section{ACKNOWLEDGEMENTS}

We are grateful to our respondents for their valuable time and insights.

\section{REFERENCES}

Costanza, R., and C. Folke. 1997. "Valuing Ecosystem Services with Efficiency, Fairness, and Sustainability as Goals." In Nature's Services: Societal Dependence on Natural Ecosystems, 49-70. Washington DC and California: Island Press.

Dhiman, R. C. 2001. "Traditional Initiatives in Participatory Forest Management: Dodra-Kwar (Shimla-HP) Experience.” Indian Forester 127 (8): 929-935. 
Guha, R. 2001. “The Prehistory of Community Forestry in India." Environmental History 6 (2): 213-238. https://doi.org/10.2307/3985085

Gupta, H. K. 2006. "Cultural Significance of Indigenous Institutions and Forest Management Practices in the Indian Himalayas: Implications for Policy and Sustainable Livelihoods." Eleventh Conference of the International Association for the Study of Common Property on 'Survival of the Commons: Mounting Challenges and New Realities', Bali, Indonesia, June 19-23, 2006.

https://www.researchgate.net/publication/42761964 Cultural Significance of In digenous Institutions and Forest Management Practices in the Indian Himala yas Implications for Policy and Sustainable Livelihoods.

Kumar, M., and P. Kumar. 2008. "Valuation of the Ecosystem Services: A Psychocultural Perspective.” Ecological Economics 64 (4): 808-819.

https://doi.org/10.1016/j.ecolecon.2007.05.008

Lele, S. 2019. "Understanding Current Forest Policy Debates through Multiple Lenses." Ecology, Economy and Society - the INSEE Journal 2 (2): 21-30.

https://doi.org/10.37773/ees.v2i2.71

MOTA. 2007. Forest Rights Act 2006, Act, Rules and Guidelines. New Delhi: Ministry of Tribal Affairs, Government of India.

Singh, C. 1998. Natural Premises, Ecology and Peasant Life in the Western Himalaya 18001950. New Delhi: Oxford University Press.

Vasan, S., and S. Kumar. 2006. "Situating Conserving Communities in their Place: Political Economy of Kullu Devban." Conservation and Society 4 (2): 325-346. 